\title{
Immunogenicity of the live attenuated (Smithburn) Rift Valley fever vaccine in sheep, goats, cattle, buffaloes and camels
}

\author{
K.M. Ammar ${ }^{1}$, Nirmeen G. Shafiek ${ }^{2}$, M.S.Wassel ${ }^{2}$

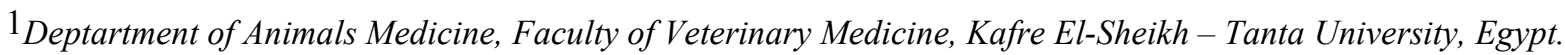 \\ ${ }^{2}$ Central Laboratory for Evaluation of Veterinary Biologics, Abbassia, Cairo, Egypt.
}

\begin{abstract}
In the present study, the humoral immune response developed following vaccination with the live-attenuated (Smithburn) Rift Valley fever (RVF) vaccine in sheep, goats, cattle, buffaloes and camels was investigated.

Results showed that, serum neutralizing antibody titers of RVF virus started to appear in the sera of all vaccinated animals with live-attenuated Rift valley fever vaccine after the first week post-vaccination and reached its peak after the third month of vaccination. It persisted to be higher than the acceptable limit of protection $(>40)$ in the sera of sheep and goats in more than 6 months post-vaccination while it declined in the sera of cattle, buffaloes and camels to become lower than the acceptable limit of protection $(<40)$ after the sixth month post-vaccination. On the other hand, the serum neutralizing antibody titers remained negative in the sera of non-vaccinated (control) animals throughout the study.

It could be concluded that, the neutralizing antibodies following vaccination of cattle, buffaloes and camels with live attenuated RVF (Smithburn) vaccine was low and of a short duration compared with those in sheep and goats. Hence, it is important to prepare a new vaccine which is safe and gives a high immune response for long period in cattle, buffaloes and camels instead of live attenuated (Smithburn) RVF vaccine to protect these animals species against this disease.
\end{abstract}

Rift Valley fever (RVF) is an acute mosquito-borne viral disease affecting animals and man it is caused by a virus that belongs to genus Phlebovirus, Bunyaviridae, (Kahrs, 2001). It causes high rate of abortion and neonatal mortality, primary in sheep, goats and cattle (OIE, 1996). RVF is confined essentially to Africa in association with dense populations of arthropod vectors (House et al., 1992). The disease was first described by Daubney et al. (1931) in the Rift valley in Kenya. In Egypt, the first epidemic of RVF appeared in 1977-1978 as an acute febrile dengue like illness affecting man as well as animals (Imam and Darwish, 1977 and WHO, 1977). Further waves of the disease appeared in 1979-1980; (Abdel Gaffar et al., 1979; Meegan et al., 1979; El-Akked et al., 1981; Seller et al., 1982 and Allam, 1987) and in May 1993 up to September 1994 in Aswan, Sharkia and some other provinces in Egypt (Arthur et al., 1993; Gabery et al., 1994 and Abou Zaid et al., 1995) and recently in summer 2003 in Cidy Salem at Kafre El-Shiekh province leading to high rate of abortion in pregnant sheep, goats, cattle and buffaloes and deaths in humans with an ocular, nervous and hemorrhagic symptoms (WHO, 2003).
Control of RVF depends mainly on periodical vector control and vaccination of the susceptible animals (Kahrs, 2001). However, immunization of susceptible animals with a potent and highly immunogenic vaccine is considered the most effective mechanism for control of the disease (Wilson, 1994). Smithburn (1949) prepared live attenuated vaccine, which can protect non-pregnant animals for long period. This vaccine was proved to be immunogenic and gave good protection for sheep and goats against infection with RVF for several months (Hassan et al., 2001; Shafiek, 2002 and Lilys et al., 2003). However, the immunogenicity of this vaccine in other animal species is still uncertain.

The aim of the present investigation was to study the elicited humoral immune response following vaccination of sheep, goats, cattle, buffaloes and camels with live attenuated (Smithburn) RVF vaccine.

\section{Material and Methods}

Animals. Thirty-five apparently healthy animals (sheep, goats, cattle, buffaloes and camels; 7 of each) of about one-year age with no previous history of Rift Valley fever vaccination were used. 
Vaccine. Live attenuated (Smithburn) RVF vaccine was kindly obtained from Rift valley fever Production Department, Serum and Vaccine Research Institute, Abbassia, Egypt.

Serum neutralization test (SNT). it was used for measurement of neutralizing antibody titers of RVF in the sera of investigated animals and was done according to Walker et al., (1970). The antibody titers were calculated as the reciprocal of the final serum dilution that inhibited the CPE of $100-200 \mathrm{TCID}_{50}$ of the used virus according to Singh et al., (1967).

Experimental design. animals were kept under observation for 7 days before vaccination. General clinical examination was carried out and serum samples were collected for detection of RVF antibodies. Animals of each species were randomly divided into two groups: Group (1) Five animals were vaccinated with $2 \mathrm{ml}\left(2 \times 10^{4.5}\right.$ $\mathrm{ICID}_{50} / \mathrm{ml}$ ) (OIE, 1996) of live-attenuated (Smithburn) RVF vaccine.

Group (2) Two animals were kept as control (non vaccinated). Serum samples were collected from both groups of all animal species after 1, 2, 3 weeks and 1, 2, 3, 4, 5, 6 and 7 months postvaccination and subjected to serum neutralization test for measurement of the neutralizing antibody titers of RVF virus.

\section{Results}

Means of neutralizing antibody titers, following vaccination of live-attenuated (Smithburn) Rift valley fever vaccine, in the sera of different animal species are shown in Tables 1-5 and Figures 1-5.

Table (1): Means of serum neutralizing antibody titers in sheep vaccinated with live-attenuated RVF (Smithburn) vaccine.

\begin{tabular}{|c|c|c|c|c|c|c|c|c|c|c|c|}
\hline \multirow{3}{*}{ Vaccinal state } & \multicolumn{11}{|c|}{ Means of serum neutralizing antibody titers } \\
\hline & \multirow{2}{*}{0 day } & \multicolumn{4}{|c|}{ Week post-vaccination } & \multicolumn{5}{|c|}{ Month post-vaccination } & \multirow[b]{2}{*}{7} \\
\hline & & 1 & 2 & 3 & 1 & 2 & 3 & 4 & 5 & 6 & \\
\hline Vaccinated & - & 8 & 16 & 32 & 64 & 128 & 256 & 256 & 256 & 256 & 256 \\
\hline $\begin{array}{l}\text { Non vaccinated } \\
\text { (control) }\end{array}$ & - & - & - & - & - & - & - & - & - & - & - \\
\hline
\end{tabular}

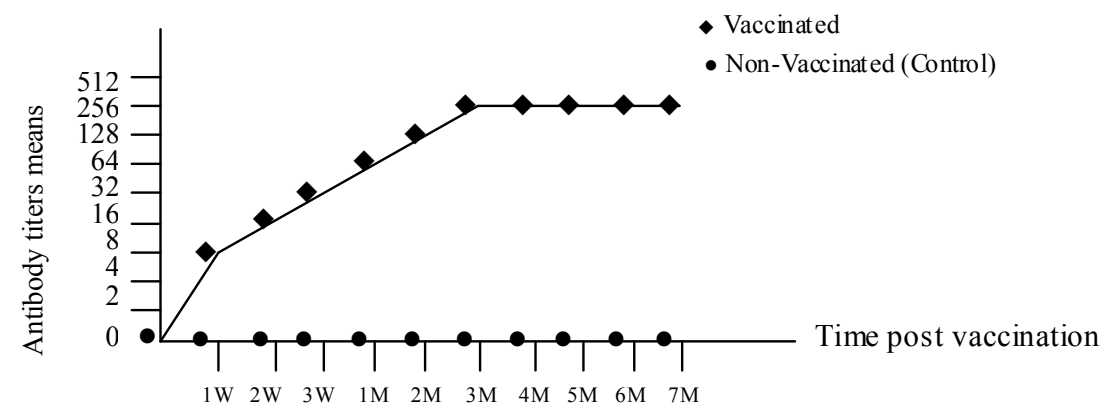

Fig. 1. Means of neu tralizing antibody titers of RVF virus in the sera of sheep. 
Table (2): Means of serum neutralizing antibody titers in goats vaccinated with live-attenuated RVF vaccine.

\begin{tabular}{|c|c|c|c|c|c|c|c|c|c|c|c|}
\hline \multirow{3}{*}{ Vaccinal state } & \multicolumn{11}{|c|}{ Means of serum neutralizing antibody titers } \\
\hline & \multirow{2}{*}{0 day } & \multicolumn{3}{|c|}{ Week post-vaccination } & \multicolumn{7}{|c|}{ Month post-vaccination } \\
\hline & & 1 & 2 & 3 & 1 & 2 & 3 & 4 & 5 & 6 & 7 \\
\hline Vaccinated & - & 4 & 8 & 16 & 32 & 64 & 128 & 128 & 128 & 128 & 128 \\
\hline $\begin{array}{l}\text { Non vaccinated } \\
\text { (control) }\end{array}$ & - & - & - & - & - & - & - & - & - & - & - \\
\hline
\end{tabular}

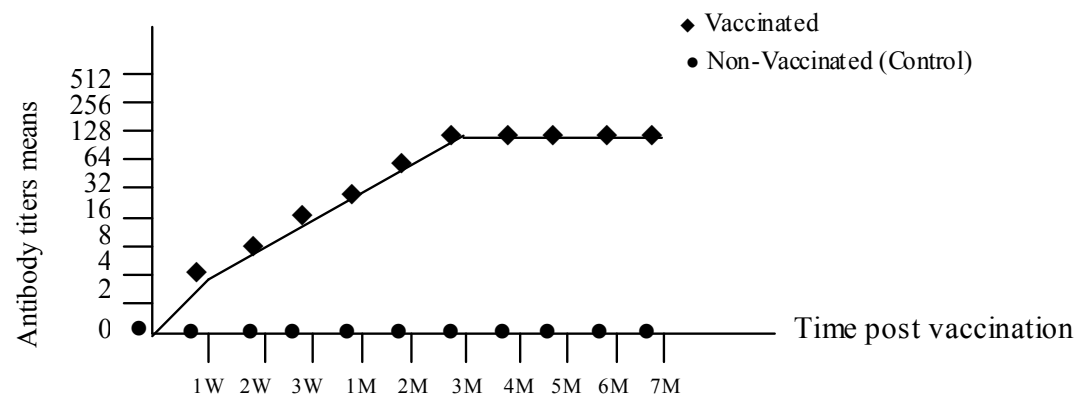

Fig. 2. Me ans of neutralizing antibody titers of RVF virus in the sera of goats.

Table (3): Means of serum neutralizing antibody titers in cattle vaccinated with live-attenuated RVF (Smithburn) vaccine.

\begin{tabular}{|c|c|c|c|c|c|c|c|c|c|c|c|}
\hline \multirow{3}{*}{ Vaccinal state } & \multicolumn{11}{|c|}{ Means of serum neutralizing antibody titers } \\
\hline & \multirow{2}{*}{0 day } & \multicolumn{3}{|c|}{ Week post-vaccination } & \multicolumn{7}{|c|}{ Month post-vaccination } \\
\hline & & 1 & 2 & 3 & 1 & 2 & 3 & 4 & 5 & 6 & 7 \\
\hline Vaccinated & - & 2 & 4 & 8 & 16 & 32 & 64 & 64 & 64 & 32 & 32 \\
\hline $\begin{array}{l}\text { Non vaccinated } \\
\text { (control) }\end{array}$ & - & - & - & - & - & - & - & - & - & - & - \\
\hline
\end{tabular}

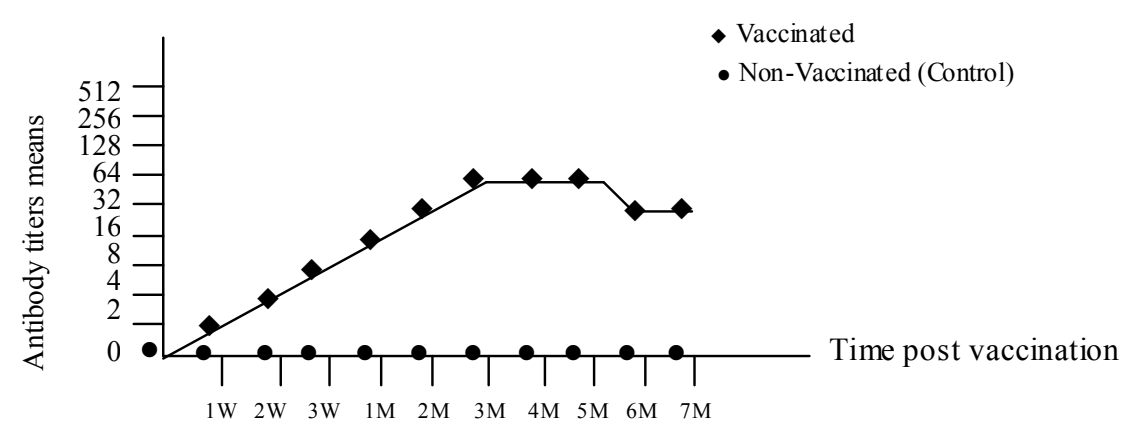

Fig 3: Means of neutralizing antibody titers of RVF vir us in the sera of cattle. 
Table (4): Means of serum neutralizing antibody titers in buffalos vaccinated with live-attenuated RVF (Smithburn) vaccine

\begin{tabular}{|c|c|c|c|c|c|c|c|c|c|c|c|}
\hline \multirow{3}{*}{ Vaccinal state } & \multicolumn{11}{|c|}{ Means of serum neutralizing antibody titers } \\
\hline & \multirow{2}{*}{0 day } & \multicolumn{3}{|c|}{ Week post-vaccination } & \multicolumn{7}{|c|}{ Month post-vaccination } \\
\hline & & 1 & 2 & 3 & 1 & 2 & 3 & 4 & 5 & 6 & 7 \\
\hline Vaccinated & - & 2 & 2 & 8 & 16 & 32 & 64 & 64 & 32 & 32 & 16 \\
\hline $\begin{array}{l}\text { Non vaccinated } \\
\text { (control) }\end{array}$ & - & - & - & - & - & - & - & - & - & - & - \\
\hline
\end{tabular}

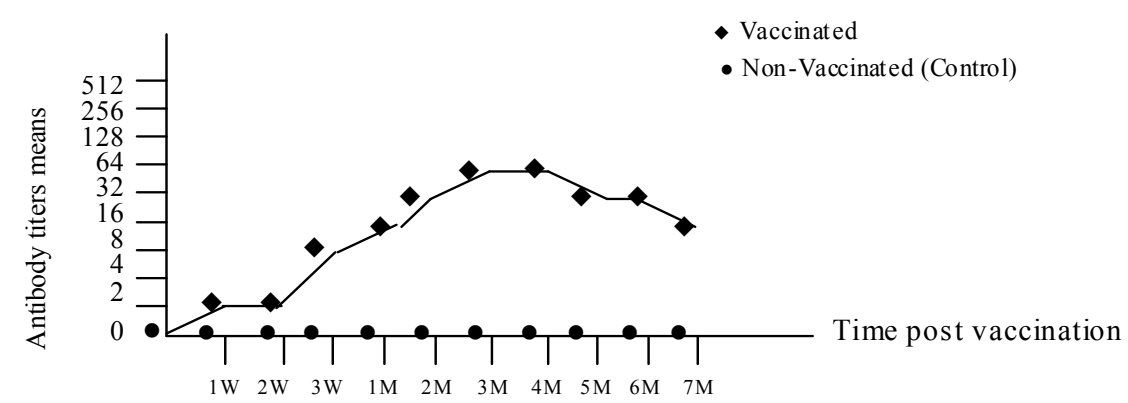

Fig. 4: Means of neutralizing antibody titers of RVF virus in the sera of buffaloes.

Table (5): Means of serum neutralizing antibody titers in camel vaccinated with liveattenuated RVF (Smithburn) vaccine.

\begin{tabular}{|c|c|c|c|c|c|c|c|c|c|c|c|}
\hline \multirow{3}{*}{ Vaccinal state } & \multicolumn{11}{|c|}{ Means of serum neutralizing antibody titers } \\
\hline & \multirow{2}{*}{0 day } & \multicolumn{3}{|c|}{ Week post-vaccination } & \multicolumn{7}{|c|}{ Month post-vaccination } \\
\hline & & 1 & 2 & 3 & 1 & 2 & 3 & 4 & 5 & 6 & 7 \\
\hline Vaccinated & - & 4 & 4 & 8 & 16 & 32 & 64 & 64 & 64 & 64 & 32 \\
\hline $\begin{array}{l}\text { Non vaccinated } \\
\text { (control) }\end{array}$ & - & - & - & - & - & - & - & - & - & - & - \\
\hline
\end{tabular}

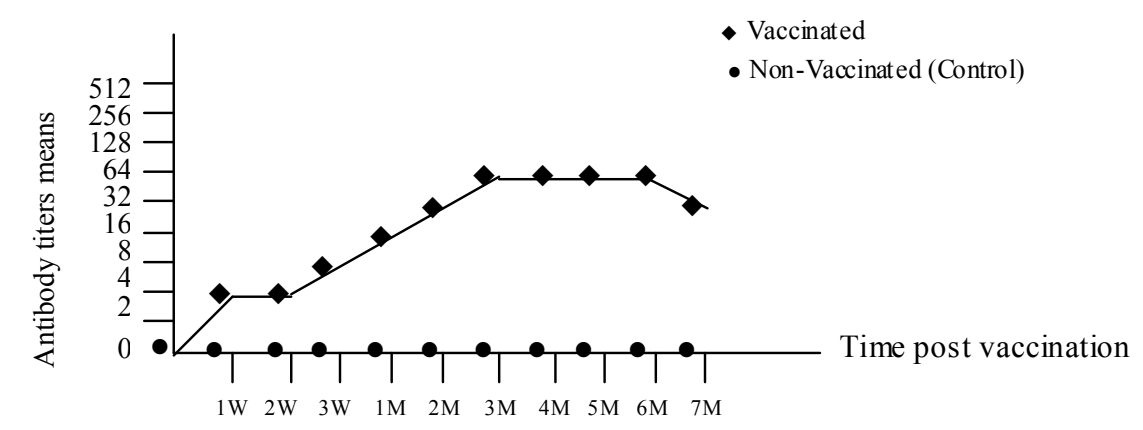

Fig. 5: Means of neutralizing antibody titers of RVF virus in the sera of camels. 


\section{Discussion}

Rift valley fever is one of the most serious zoonotic viral disease causing devastating epidemics among sheep, goats, cattle and human (Kahrs, 2001). A relatively solid and potentially life long immunity was developed following recovery from natural infection or successful vaccination with RVF (Wilson, 1994). Both live attenuated and inactivated vaccines have been developed for protection of sheep and cattle against Rift valley fever. The inactivated vaccine is effective and safe to the pregnant animals but it gives short period of immunity and needs two doses to protect them for 6 months (El-Nimr, 1980). The live attenuated Rift valley fever (Smithburn) vaccine has long period of immunity which can extend for more than 2 years (Smithburn, 1949). In this study, the neutralizing antibodies in the sera of sheep, goats, cattle, buffaloes and camels following vaccination with live attenuated (Smithburn) Rift valley fever vaccine were determined using virus neutralization test. Results showed that the neutralizing antibodies titre started to appear in the sera of vaccinated sheep and goats after the first week post vaccination, and reached its peak after the third month of vaccination and remained higher than the acceptable limit of protection $(>40)$ for more than 6 months postvaccination (Tables $1 \& 2$ and Figures $1 \& 2$ ). This finding gets in a agreement with the finding recorded by OIE (1996) and Shafiek (2002) in sheep and Hassan et al., (2001) and Lilys et al., (2003) in goats who reported that the neutralizing antibody in sheep and goats vaccinated with Smithburn live attenuated RVF vaccine were at the protective level $(>40$ as mentioned by Pini et al., 1973) from the first month post-vaccination till 3 years. Likewise, means of the serum neutralizing antibodies of RVF virus in the serum of cattle, buffaloes and camels following vaccination with live attenuated (Smithburn) RVF vaccine started to appear after the first week and reached its peak after the third month post-vaccination, but declined gradually to become less than the acceptable limit of protection $(<40)$ after sixth months post-vaccination (Tables $3,4 \& 5$ and Figures $3,4 \& 5$ ). This means that this vaccine cannot stimulate the immune system of these species for long duration to produce enough antibodies. This finding confirms the finding of Swanepoel (1981); Elian et al., (1996) and Shafiek et al., (2004) who said that the live attenuated (Smithburn) Rift valley fever vaccine is poorly immunogenic in cattle. On the other hand, the serum neutralizing antibody titers RVF in the sera of non vaccinated contact (control) animals remained negative throughout the study (Table 1-5 and Fig. 1-5). This means that, there is no lateral transmission of infection with vaccinal strain from the vaccinated to non vaccinated contact animals.

From the above mentioned results, we can say that humoral immune response following vaccination of cattle, buffaloes and camels with live attenuated (Smithburn) vaccine is low and of short duration if compared with those in sheep and goats. This might be due to the poor immunogenicity of the Smithburn vaccine in other animal species. Therefore, it is important to prepare a new vaccine which is safe and gives a high immune response for long period in cattle, buffaloes and camels instead of live attenuated (Smithburn) RVF vaccine to protect these animal species against this disease.

Such findings clarify the urgent need to prepare safe and highly immunogenic vaccine for immunization of cattle, buffaloes and camels.

\section{References}

Abdel-Gaffar, S.; Mohsen, A. Y.; Ayob, N. K.; ElNimer, M. M.; Aida El-Debegy (1979): Rift valley fever in Egypt. J. of Egypt. Vet. Med. Assoc., 39 (1): 39-44.

Abou Zaid, A. A.; Nakshly, S. A.; Nasr, M. Y.; Mokhbatly, A. A. and Khafagy, A.A. (1995): Studies on Rift valley fever in sheep. J. Egypt. Vet. Med. Assoc., 55 (1,2): 229-351.

Allam, I. H. (1987): "RVF epidemiology, diagnosis and control in Egyptian livestock" Final Technical report Gran. No. F.G. 197. AHRI, Dokki, Giza, Egypt.

Arthur, R. R.; El-Sharkawy, M. S.; Copes, E.; Botros, B. A.; Oun, S.; Morrill, J. C.; Shope R. E.; Hibbs, R. G.; Darwish M. A. and Imam, I. Z. E. (1993): "Rift valley fever in Egypt". Lancet, 342: 1149-1150.

Daubney, R.; Hudson, J. R. and Graham, P. C. (1931): Rift valley fever or enzootic hepatitis as undescribed diseases of sheep, cattle and man from East Africa. J. Path. Bact., 34 (1): 545-579.

El-Akkad, A. M. (1981): Recent epidemiological status of RVF in Egypt from 1975-1980. J. Egypt. Public Health Assoc. ,LVI $(5,6)$ : 351-355.

Elian, K. A.; Wassel, M. S.; Gihan, K. M. and ElDebegy, A. T. (1996): Serological studies following vaccination with Rift valley fever vaccine in Egypt. $4^{\text {th }}$ Scient. Cong. for Cattle Dis. 3-7 April. Vet. Med. J. Giza, 44 (2): 409-417.

El-Nimr, M. M. H. (1980): "Studies on the inactivated vaccines against RVF" $\mathrm{Ph}$. D. thesis Microbiology. Fac. Vet. Med. Assuit Univ., Egypt.

Gabery, G. H.; Nawal, M. A., Hadia, A.; Fathia, M. M. and Ayoub, N. N. (1994): Unclassical picture of RVF in man and animals in Aswan Governorate in May 1983. Vet. Med. J., Giza, 42 (1): 133-139.

Hassan, K. Z.; Elian, K. A. and Taha, M. M. (2001): Some studies on sheep vaccinated with Smithburn attenuated Rift valley fever vaccine. Egypt. J. Agric. Res., 
79 (3) 2001.

House, J. A; Turell, M. J. and Mebus, C. A. (1992): Rift valley fever present status and risk to the western hemisphere. Ann. N.Y. Acad. Sci., 653: 233-242.

Kahrs, R.F (2001): Viral diseases in cattle. $2^{\text {nd }}$ ed. Iowa state university Press/Ames, Lowa 50014 pp. 287-292.

Imam, Z. E. I. and Darwish, M. A. A. (1977): Report on an epidemic of RVF in Egypt. J. Egypt. Pub. Health Assoc., 52: 417-418.

Lilys, S.; Younis, E. E.; Hassan, K. E. Z.; El-Sawalhy, A. A. and Khairat, A. E. (2003): Immunological studies on goats vaccinated with Rift valley fever vaccines. $7^{\text {th }}$ Sci Cong. Egyptian Society for Cattle Diseases, Assiut, Egypt.

Meegan, J. M.; Hoogstral, H. and Moussa, M. I. (1979): An epizootic of RVF in Egypt in 1977. Vet. Rec., 105: 124125.

Shafiek, N. G. (2002): Studies on the evaluation of modified living attenuated Rift valley fever virus vaccine. Ph.D. Thesis, Virology. Fac. Vet. Med. Cairo Univ., Egypt. Shafiek, N. G.; El-Nagger, A. H. and Wassel, M.S. (2004): Evaluation of the immunity following vaccination with attenuated Rift valley fever vaccine in cattle. Menufia Vet. J., 3 (2): 441-448.

OIE (1996): Office International Des Epizootics. World Organization for Animal Health. Manual of standards for diagnostics test and vaccines.
Pini, A.; Lund, L. J. and Davis, S. J. (1973): Fluorescent and neutralizing antibody response to injection by Rift valley fever. J.S. Afr. Z. Med. Assoc., 44 (11): 161-165.

Seller, R. F.; Peolyley, P. E. and Tucken, M. R. (1982): Rift valley fever in Egypt, disease spread by windborne insect vectors. Vet. Rec., 110: 73-77.

Singh, K. V.; Osman, O. A.; El-Cicy, L. E.; Ata, F. A. and Baz, T. I. (1967): Response of water buffaloes to experimental injection with rinder pest virus. Cornell. Vet., 57: 638-648.

Smithburn, K. C. (1949): Rift valley fever. The neurotropic adaptation of virus and experimental use of this modified virus as a vaccine. Br. J. Exp. Path., 30: 1-6.

Swanepoel, R. (1981): Rift valley fever in Zimbabwe, proceedings of the $49^{\text {th }}$ General Session of the Office International de Epizootic, Paris. 75-30 may.

Walker, J. S.; Stephen, E. L.; Remmel, N. S.; Carter, R. C. Mitten, J. W.; Sohuli, L. J. and Klein, S. (1970): The clinical aspect of RVF in house holds pets. J. Inf. Dis., 121:9-24.

Wilson, M. L. (1994): Rift Valley fever virus ecology and epidemiology of disease emergence. Ann. N.Y. Acad. Sci., 740: $169-180$.

WHO (1977): Rift valley fever. World Health Organization, Weekly epidemiological Rec., 50: 401.

WHO (2003): Rift valley fever. World Health Organization Fact sheets No. 207. 